\title{
A Built-in Criteria Analysis for Best IT Governance Framework
}

\author{
HAMZANE Ibrahim ${ }^{1}$, Belangour Abdessamad ${ }^{2}$ \\ Ben M'sik Faculty of Science, Hassan 2 University \\ Casablanca, Morocco
}

\begin{abstract}
The implementation of IT governance is important to lead and evolve the information system in agreement with stakeholders. This requirement is seriously amplified at the time of the digital area considering all the new technologies that have been launched recently (Big DATA, Artificial Intelligence, Machine Learning, Deep learning, etc.). Thus, without a good rudder, every company risks getting lost in a sea endless and unreachable goal. This paper aims to provide decision-making system that allows professionals to choose IT governance framework suitable to desired criteria and their importance based on a multi-criteria analysis method (WSM), we did implement a case study based on a Moroccan company. Moreover, we present a better understanding of IT Governance aspects such as standards and best practices. This paper goes into a global objective that aims to build an integrated generated meta-model for a better approach of IT Governance.
\end{abstract}

Keywords-IT Governance; COBIT; ISO 38500; CMMI; ITIL; TOGAF; PMBOK; PRINCE 2; SCRUM

\section{INTRODUCTION}

IT is a business asset that is gaining a lot of importance in the last decades in every industry especially regarding the spread of new technologies.

Following the statistics provided by the Club of Large French IT Companies (CIGREF) in 2017, 51\% of companies rely on COBIT for the governance of their information systems (IT), while $16 \%$ use internal processes and $32 \%$ are not inspired by COBIT in the world [22]. Moroccan companies have to make a lot of effort regarding IT governance [20].

The goal of this paper is to provide the most complete IT governance approach based on existing models and complement this research with other best practices in several IT domains. In this paper, we will clarify the difference between several concepts similar to the definition of the standards. Then, we will carry out a comparative study between the different frameworks specifying their strengths and weaknesses then we will implement a decision system based on the analysis of a Moroccan company. Thus, companies can weigh the criteria and produce the choice of reference to adopt based on their own needs.

\section{StAndards Vs Best PRACTICES}

Outside, when we focus on governance practices specifically in IT governance, we come across several sources (ITIL, CNIL, SOX, CMMI, ISO 9001, ISO 9002, ISO 14000, ISO 17799, ISO 27001, 27002, 27003, 27005...) each reference offer a partial view of IT Governance [10]. Thus, for better governance of this paper, we will first make a vocabulary distinction between theses references then we will define IT governance.

\section{A. Standards}

According to the International Organization for Standardization (ISO) and the International Electro-technical Commission (IEC): the standard is "a document established by consensus and approved by a recognized body, which provides, for common and repeated use, rules, guidelines or features, for activities or results that guarantee an optimal level of order in a given context." [1].

As consequence, standards are based on a tiered model can be recognized (certified or evaluated) by their own organization, it's a listing or a set of requirements to be fulfilled in order to claim the certification of the management systems of an organization, in a given management domain (services, information security, governance, etc.).

Find below some examples of standards:

- ISO 38500; Helps business leaders to ensure that the use of IT assets positively and contributes to the performance of the organization by meeting the requirements of ISO/IEC 38500, organizations are able to monitor the use of IT, ensure business continuity and sustainability, align IT assets to business needs and ensure proper implementation and operation of IT assets [16].

- ISO 9001; Standard that establishes the requirements for a quality management system. It helps businesses and organizations become more efficient and increase customer satisfaction [21].

\section{B. Best Practices}

Whereas best practices are a set of behaviors to adopt and adapt to effectively manage a given aspect of IT (governance, value and quality of services, projects, processes, application development, development architecture, etc.) that are considered essential by most professionals in the field, it can be found in the form of guides to good practice such as SCRUM or adopted by organization such as PRINCE 2 (organization), ITIL (organization) or COBIT (ISACA).

Best practices are generally based on 2 types of models:

- Stepped models; structured by maturity levels; For example CMMI, eSCM-CL 
- "Continuous" or "Cyclical" models; structured by skill or phase domain; For example ITIL 2011, TOGAF 9.2, COBIT 5.

It should be noted that CMMI proposes both approaches. Below some definitions of most commune best practices used in IT services.

- CMMI: Capacity Maturity Model Integrated is a model for assessing the maturity level of a company in terms of IT developments [7]. Developed in 1987 by the Carnegie Mellon University Software Engineering Institute, CMMI is a model for the development and maintenance of computer systems and applications designed to capture, evaluate and improve the operations of engineering firms [3].

- COBIT: A framework for the development, implementation, supervision, improvement of the governance and administration practices of information systems. The COBIT framework is published by the IT Governance Institute and ISACA. Its purpose is to provide a common language for business leaders to discuss together their goals, objectives and results [16].

- TOGAF: The Open Group Architecture Framework is a set of concepts and an industry-standard covering the field of enterprise IT architectures [17].

- ITIL: Information Technology Infrastructure Library framework enables information technology (IT) to play a service delivery role rather than just specialized support [11], [12], [13], [14], and [15]. ITIL guidelines and best practices aim to adapt IT actions and budget to business needs and modify them as the company grows or changes direction. The goal is to improve efficiency and achieve predictable levels of service [9].

- PMBOK: Project Management Body Of Knowledge is a project management guide designed and produced by the PMI Project Management Institute. This fairly extensive guide aims to stabilize and structure the current knowledge needed to run a project in the best conditions [6]. It is a knowledge base on project management. It defines the fields of knowledge related to this field and describes the good practices to implement.

- PRINCE 2: PRojects IN Controlled Environment is a method developed by the British government and accredited by Axelos, based on best practices in project management. This flexible methodology applies to all companies and only for a defined scope project. "Built upon seven principles, themes and processes, PRINCE2 can be tailored to meet specific requirements" [19].

- SCRUM: An agile project management methodology, it is used particularly in software development. It's "A framework within which people can address complex adaptive problems, while productively and creatively delivering products of the highest possible value." [18].

\section{IT GOVERNANCE}

Governance is the set of processes that tend to harmonize the world of business, projects, and experience [4].

According to CIGREF, governance is closely linked to the notion of company management.

IT governance [2]: "Organizational capacity exercised by the management committee, senior management and IS managers to oversee the formulation and implementation of the IS strategy".

The ITGI provides business executives and boards of directors with original research, online resources and case studies to help them meet their responsibilities in the area of IT governance.

It designed and authored COBIT V4.1, essentially as a teaching resource for information managers, general management, Information System management and control professionals [5].

Today, IT governance as defined by ITGI and ISACA boils down to the following five issues:

- IT Strategic Alignment

- IT Value Delivery

- IT Risk Management

- Performance Measurement

- IT Resource Management

According to the ISO, there are 6 guiding principles for corporate governance that apply to most organizations. The ISO specifies that each principle refers to what should exist, but does not describe how, when or by whom these principles are to be implemented. Nevertheless, decision-makers must demand that these principles be applied.

- Principle 1: Responsibility

- Principle 2: Strategy

- Principle 3: Acquisition

- Principle 4: Performance

- Principle 5: Compliance

- Principle 6: Ethics

\section{COMPARATIVE STUdy OF IT GOVERNANCE REFERENCES}

\section{A. SWOT Analysis}

Table I present a minimal SWOT analysis to summarize the strengths and weaknesses of the references: 
TABLE. I. SWOT ANALYSIS MINIMAL

\begin{tabular}{|c|c|}
\hline \multicolumn{2}{|l|}{ CMMI } \\
\hline \multirow{4}{*}{ Positives } & $\begin{array}{l}\text { Improve the quality of the product delivered and the } \\
\text { productivity of the project }\end{array}$ \\
\hline & $\begin{array}{l}\text { Increase customer satisfaction by better meeting its } \\
\text { requirements }\end{array}$ \\
\hline & Reduce costs and meet deadlines \\
\hline & $\begin{array}{l}\text { Give better visibility to management and enable better } \\
\text { risk management }\end{array}$ \\
\hline \multirow[b]{2}{*}{ Negatives } & The lack of precision. \\
\hline & $\begin{array}{l}\text { The level of maturity being global, it can mask areas of } \\
\text { the organization that perform less well than others } \\
\text { perform and hides gaps in certain process areas. }\end{array}$ \\
\hline \multicolumn{2}{|r|}{1} \\
\hline \multirow{5}{*}{ Positives } & Meeting the needs of stakeholders \\
\hline & Cover the entire company from end to end \\
\hline & Application of a single Framework \\
\hline & Provide a holistic approach to business decision-making \\
\hline & Separating the governance from the management \\
\hline \multirow{2}{*}{ Negatives } & Difficulty of implementation \\
\hline & Management guide not known in the framework \\
\hline \multicolumn{2}{|l|}{ TOGAF } \\
\hline \multirow{5}{*}{ Positives } & A common language within the company \\
\hline & $\begin{array}{l}\text { Strength of the information system (as the growing } \\
\text { complexity of IS) }\end{array}$ \\
\hline & Maximize IT value \\
\hline & $\begin{array}{l}\text { Use a common framework to facilitate the search for } \\
\text { skills }\end{array}$ \\
\hline & Achieve a better quality of products \\
\hline Negatives & Does not cover management processes \\
\hline \multicolumn{2}{|l|}{ ISO 38500} \\
\hline \multirow{3}{*}{ Positives } & $\begin{array}{l}\text { Assuring all stakeholders (including customers, } \\
\text { shareholders, and employees) that if the standard is } \\
\text { applied, they can trust the IT governance of their } \\
\text { organization }\end{array}$ \\
\hline & $\begin{array}{l}\text { Informing and guiding leaders to steer the use of } \\
\text { computers in their organization }\end{array}$ \\
\hline & $\begin{array}{l}\text { Providing a framework for an objective assessment of the } \\
\text { company's IT governance }\end{array}$ \\
\hline \multirow[b]{2}{*}{ Negatives } & Framework designed for top management. \\
\hline & $\begin{array}{l}\text { Does not cover support services, the build, and } \\
\text { implementation services }\end{array}$ \\
\hline \multicolumn{2}{|r|}{ I } \\
\hline \multirow{7}{*}{ Positives } & Time-saving \\
\hline & Cost reduction \\
\hline & Defining more precise roles and responsibilities \\
\hline & Better user satisfaction \\
\hline & Better productivity/efficiency \\
\hline & IT services of better quality \\
\hline & Adaptation to customer needs to be facilitated \\
\hline \multirow[b]{3}{*}{ Negatives } & Very little known to the general public \\
\hline & There is very little information on the Internet \\
\hline & $\begin{array}{l}\text { Complex (you have to be expert as it concerns the } \\
\text { network, system, application, BD and has a global vision } \\
\text { of the IS) }\end{array}$ \\
\hline \multicolumn{2}{|r|}{ 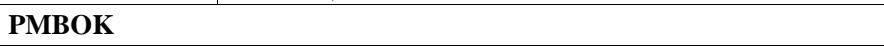 } \\
\hline \multirow[t]{2}{*}{ Positives } & $\begin{array}{l}\text { A guide to knowledge and good practice created by } \\
\text { project management professionals who update it } \\
\text { regularly. }\end{array}$ \\
\hline & $\begin{array}{l}\text { Standardize project management practices, which means } \\
\text { that each department works in the same way. }\end{array}$ \\
\hline
\end{tabular}

\begin{tabular}{|c|c|}
\hline \multicolumn{2}{|l|}{ CMMI } \\
\hline & Find the same practices from one company to another. \\
\hline \multirow{2}{*}{ Negatives } & $\begin{array}{l}\text { Respect all PMBOK processes to ensure the success of } \\
\text { the project }\end{array}$ \\
\hline & $\begin{array}{l}\text { Adapt the methodology to the size and sector of the } \\
\text { project }\end{array}$ \\
\hline \multicolumn{2}{|l|}{ PRINCE 2} \\
\hline \multirow{3}{*}{ Positives } & Rational project management. \\
\hline & $\begin{array}{l}\text { The formalism makes it possible to define logic and a } \\
\text { common vocabulary facilitating exchanges }\end{array}$ \\
\hline & Continuous learning orientation \\
\hline Negative & $\begin{array}{l}\text { Systematic rationalization disguises the real subtleties of } \\
\text { project management, in practice; project management is } \\
\text { much more complex. The realities of the field, the human } \\
\text { stakes, the immature technologies, the requirements of } \\
\text { deadlines and budgets will not be solved by the obsession } \\
\text { of the formalism }\end{array}$ \\
\hline \multicolumn{2}{|l|}{ SCRUM } \\
\hline \multirow{6}{*}{ Positives } & Increase the fluidity of release and velocity of the team \\
\hline & Easily master the risks and changes during delivery \\
\hline & Encourage orientation, rigor, and energy in the teams \\
\hline & $\begin{array}{l}\text { Increase the capacity and quality of execution relative to } \\
\text { customer requirements }\end{array}$ \\
\hline & $\begin{array}{l}\text { Substantially outperform the delivery of priority values } \\
\text { that generate results faster }\end{array}$ \\
\hline & Requires a united and motivated team \\
\hline \multirow{3}{*}{ Negatives } & Difficulty following the life cycle of a development \\
\hline & Support needed by sponsors \\
\hline & Essential adaptation phase (continuous changes) \\
\hline
\end{tabular}

\section{B. Multi-Criteria Comparative Study}

1) Multi-criteria analysis: After seeing the advantages and disadvantages of each framework, we will now develop a multi-criteria analysis between these frameworks. A MultiCriteria Decision Analysis (MCDA) is a valuable tool that can be applied to many complex decisions. It can solve complex problems that Include qualitative and/or quantitative aspects in the decision- making process.

We aim to help the decision-makers by facilitating the choice of the best framework to be used according to desired criteria and their importance.

The score of a framework is calculated based on a number of criteria. So far we have identified ten criteria; Indeed, based on the set of principles of IT governance for the ITGI and ISO 38500 , we have identified in almost complete governance pillar that will be the important criterias: IT Strategic Alignment, IT Value Delivery, IT Risk Management, IT Performance measurement, IT Acquisition, IT Resource Management, IT Responsibility, IT Compliance, IT Human Behavior and IT Control.

- C1: IT Strategic Alignment: An approach to align the information system strategy with the company's business strategy [8].

- C2: IT Value Delivery: Value creation refers to the financial purpose of companies for their IT. Value is created when investments are based on IT whose rate of return is higher than the costs that are made. 
- C3: IT Risk Management: Operational and business risk related to IT domain, it is about setting up processes to manage IT risk.

- C4: IT Performance measurement: The implementation of KPIs to achieve the objectives. In addition to the indicators, it is also the right definition of the objectives to be put in place.

- C5: IT Acquisition: The management of the service providers and the external interventions makes it possible to carry out the objectives of the IT thus good piloting of the activity IT.

- C6: IT Resource Management: The main asset of the IT division is the human resources as well as the materials used, thus good management of the resources makes it possible to obtain good governance of the IT system.

- C7: IT Responsibility: The definition of roles and responsibility is a key factor of process success so it is a pillar to carry out the adopted processes.

- C8: IT Compliance: IT regulation has evolved a lot in the last decades, with user protection laws, a good benchmark allowing a good application of IT regulations will allow better governance.

- C9: IT Human Behavior: According to the CNIL, the respect of freedom is an important axis for good IT governance; several articles describe in detail this pillar.

- C10: IT Control: Set up a set of business processes / IT with KPIs to control the execution and performance of processes.

2) Multi-criteria analysis methods: There are several possible methods to make a comparison between the frameworks using many criterias. These methods can be divided into three main families.

- Complete aggregation (top-down approach): Aggregating the $\mathrm{n}$ criteria to reduce them to a single criterion.

- Partial aggregation (bottom-up approach): Comparing potential actions or rankings to each other, and establishing between them outranking relations.

- Local and iterative aggregation: Looking primarily for a starting solution, then, we proceed to an iterative search to find a better solution.

Table II shows the different existing multi-criteria methods sorted by family:

3) Weighted Sum Method (WSM): We chose the Weight Sum Method (WSM) to apply because this method allows us to find the best possible approach by assigning a weight to each comparison criterion, it allows to take into account all the criteria according to their value and without a criterion penalizing the other criteria.
TABLE. II. MULTI-CRITERIA ANALYSIS FAMILIES [17]

\begin{tabular}{|l|l|l|}
\hline Family & Approach & Methods \\
\hline $\begin{array}{l}\text { Complete } \\
\text { aggregation }\end{array}$ & $\begin{array}{l}\text { Weighted Sum Method (WSM) } \\
\text { top-down } \\
\text { approach }\end{array}$ & $\begin{array}{l}\text { TWO WAY ANOVA } \\
\text { Weight Product Method (WPM) } \\
\text { Analytic Hierachy Process (AHP) } \\
\text { Multi Atribute Utility Theory (MAUT) }\end{array}$ \\
\hline $\begin{array}{l}\text { Partial } \\
\text { aggregation }\end{array}$ & $\begin{array}{l}\text { ELECTRE } \\
\text { Prométhée } \\
\text { approach } \\
\text { aelchior } \\
\text { Qualifex } \\
\text { Oreste } \\
\text { Regim ... }\end{array}$ \\
\hline $\begin{array}{l}\text { Local and } \\
\text { iterative } \\
\text { aggregation }\end{array}$ & Local \& & $\begin{array}{l}\text { Improving Cones Method (ICM) } \\
\text { GOAL Programming } \\
\text { iterative }\end{array}$ \\
\hline
\end{tabular}

4) Comparison criteria and weight: We present in this section the ten comparison criteria cited on which the comparative study will be based, we notice that these criteria are based on the characteristics of each of the approaches presented in the comparative study and the SWOT analysis presented by the front, we summarized all the characteristics (strengths and weaknesses) in ten global criteria to ensure better analysis and optimize the comparison.

For us, these criteria have the same importance to us, there for the WSM weight accorded will be the same and equal to "1", however as we will see further in this paper the weigh of each criterion change depending on each companies, therefore we experience a case study on which we will expose the vision of a reel company weighs.

5) Multi-criteria choice matrix: The WSM method start with filling the multi-criteria choice matrix, it's matrix columns contain the frameworks to be compared and its lines contain criteria with the weight assigned to each criterion which we agree that it's " 1 " as all the criterions have the same importance, and in cells there is the score given to each framework based on the detailed comparative study of each framework [2] [3] [5].

About the score, we will then use the maturity model, which consists of five levels of maturity to weight the criterion on each framework, each level will give a score, for example, "level 1" will leave a score of " 1 ".

We recall the definition of the five maturity levels by modifying the definitions, below the explanation of each level:

- Level 1: There is no formal method, nor coherence, nor standard, based on which the criteria would be constructed. The development process of the criteria is not described in the framework.

- Level 2: There is a consensus in the framework of how the criteria should be managed, but this has not been formalized or described. 
- Level 3: The development process of the criteria is formalized, documented and applied. Reviews are conducted with compliance and the configurations are properly managed.

- Level 4: The reference has instituted a formal metric information collection process to track and manage the criteria development process as well as the resulting systems. Indicators monitor the smooth running of processes and the respect of the quality objectives of the criteria.

- Level 5: The reference uses measures to continuously optimize the criteria development process. It describes in detail a process of correcting the aspects that would be considered insufficient, by reading the indicators allowing manage the criteria.

Table III represents the resulting multi-criteria choice matrix according to the score of each criterion.

We convert the table into a spider chart for visual purposes; we notice that there is no complete reference; however, COBIT is the most completed according to the investigation, see Fig. 1.

6) Discussion: All the components of good governance are not applicable on all the reference systems, by analyzing the results, we find that CMMI covers $62 \%$ of the components of the IT governance whereas COBIT covers $65 \%$ of the foundations of a good governance, on the other hand PMBOK presents the least percentage of application with only a rate of $43 \%$ which is normal since it does not contain a methodology but it is a set of practice project in management grouped in a reference.

We will scan the components and dissect the key values of each of the components, indicating which repositories apply them best.

We found that COBIT and CMMI respond best to strategic alignment given their commitment to corporate values with a clear definition of the processes, so they allow a comprehensible vision by the management of what is done by the company. Due to the process approach and compliance, a clear attribution of ownership and responsibilities deal with the requirements for control of the IT environment.

Value creation is present in almost all repositories because it is the essence of the implementation of IT in the company whatever the chosen repository.

Risk management is an important component of IT governance; it allows identifying risks in a clear and structured way. With a clear knowledge of all the risks a company is exposed to, it can prioritize them and take the appropriate measures to reduce losses and reduce the total cost of risk, most of the standards are based at least on strategies of risk management according to the intervention layer, whether operational or organizational.

IT governance processes are evaluated, directed and controlled. Indicators are a monitoring mechanism helping the achievement of business and IT objectives.
TABLE. III. MUlTi-CRITERIA CHOICE MATRIX

\begin{tabular}{|c|c|c|c|c|c|c|c|c|}
\hline & $\sum_{j}^{E}$ & 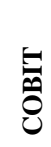 & 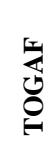 & 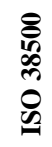 & $\Xi$ & 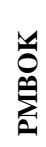 & 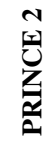 & $\sum_{\mathscr{D}}$ \\
\hline $\mathrm{C} 1$ & 4 & 4 & 3 & 3 & 3 & 1 & 3 & 3 \\
\hline $\mathrm{C} 2$ & 3 & 4 & 4 & 4 & 4 & 3 & 3 & 3 \\
\hline C3 & 3 & 4 & 4 & 2 & 3 & 5 & 5 & 4 \\
\hline C4 & 4 & 5 & 3 & 4 & 3 & 4 & 4 & 4 \\
\hline C5 & 1 & 2 & 2 & 1 & 1 & 1 & 1 & 1 \\
\hline C6 & 1 & 1 & 2 & 1 & 2 & 4 & 2 & 2 \\
\hline C7 & 4 & 3 & 1 & 3 & 1 & 1 & 1 & 1 \\
\hline C8 & 3 & 2 & 2 & 1 & 1 & 1 & 1 & 1 \\
\hline C9 & 3 & 3 & 3 & 3 & 3 & 2 & 2 & 2 \\
\hline $\mathrm{C} 10$ & 4 & 4 & 2 & 2 & 3 & 1 & 5 & 1 \\
\hline
\end{tabular}
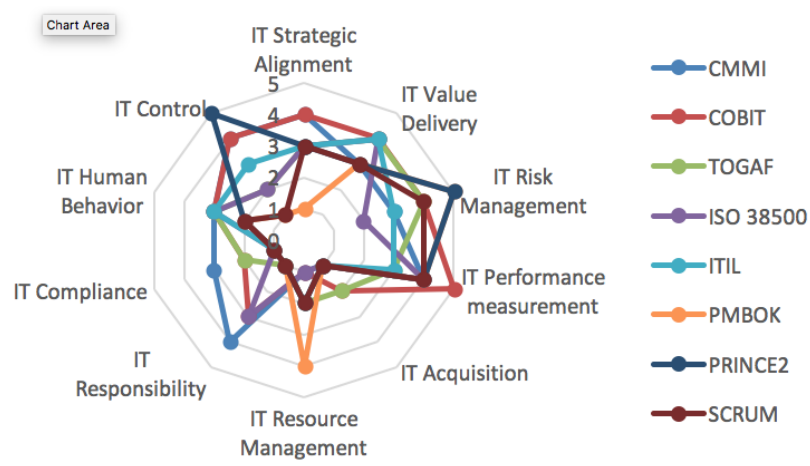

Fig. 1. Spider Chart Multi-Criteria Decision.

As a result, there is no complete repository of IT governance, however, the most complete reference is COBIT given the positions it takes on each of the components.

\section{CASE StUdy}

We consulted the company USA HOME, a company specialized in cameras installation, maintenance of pointing software, and office installation. Given the competition in the Moroccan market, the Chief Executive Officer (CEO) wants to optimize its IT resources and apply IT Governance to its IT department.

The study explained above lead us to build an application form to get the interests of the company on every criterion, below the result given by the CEO of USA HOME (Fig. 2).

Following the input of the CEO, the Multi-Criteria Choice Matrix has changed through the formula (1) below:

$$
(5 * \mathrm{a} * \mathrm{P}) / \mathrm{S}=\mathrm{P}
$$

$\mathrm{P}^{\prime} \quad$ New score following the preferences of the company

$\mathrm{P} \quad$ Initial score produced

a Weight according to the company

S Sum of weights regarding all the criterions 


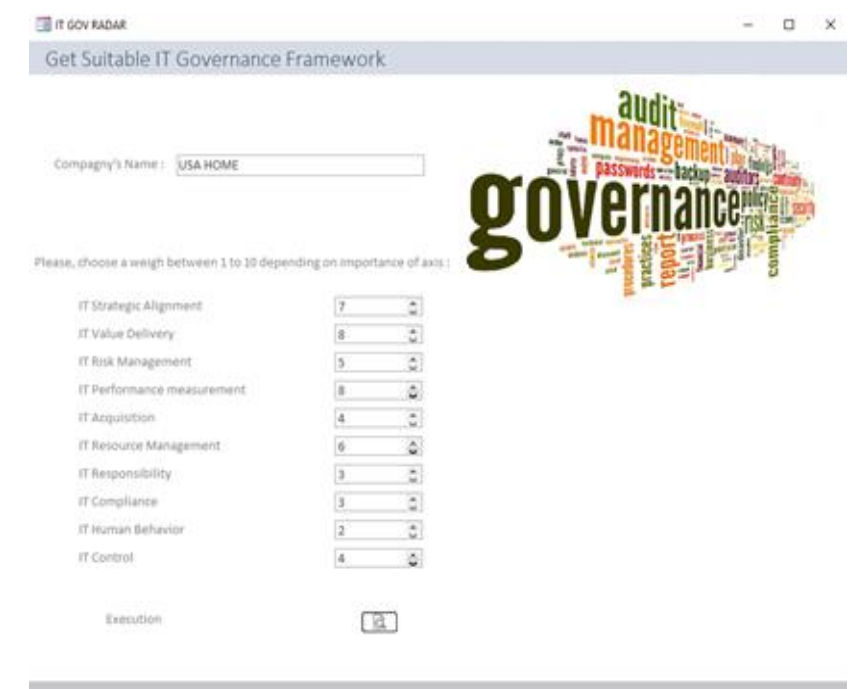

Fig. 2. The Application form that was Given to the Company USA HOME.

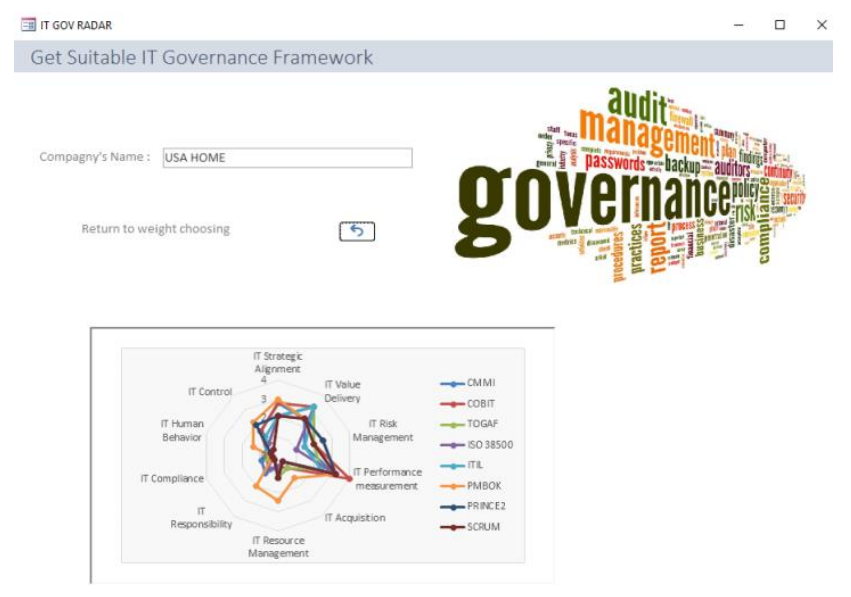

Fig. 3. Spider Chart Multi-Criteria Decision of USA HOME.

As a result, Spider chart Multi-Criteria Decision has changed according to the company's need (Fig. 3).

According to the Multi-Criteria Decision form, PMBOK will be a good reference based on the company USA HOME requirements. It will allow the company to enhance the potential of creativity, ensuring the realization and coordination of project actors and available resources according to the defined plan, it's also an effective way for a company very concerned by the projects.

\section{CONCLUSION AND FUTURE WORK}

IT assets have become directly linked to the results of the business; as the launch of new technologies and the digitalization of companies in all domains. Thus, the implementation of IT governance is important to lead and evolve the information system in agreement with stakeholders.

The choice of an IT governance framework is very important task before the implementation, a good choice will lead to a better result, this article has enabled us to implement a decision system according to the company needs; also, to understand the IT governance framework regarding their advantages and disadvantages.

We have seen that all frameworks have many challenges especially in covering all business areas and the difficulty of implementation. As future work, we will present solutions for these issues. This work gives a contribution for professionals to help them choose between different existing framework, and this according to their needs and criteria that matter most to them, as we have seen in the case study.

\section{REFERENCES}

[1] Alexandre Steigmeier, Rolf Hauri, Gouvernance de la sécurité: comment articuler les différentes normes et méthodes, Novembre 2009.

[2] The National Computing Center, developing a successful governance startegy, Novembre 2005.

[3] Jarke, M. Mylopoulos,J. Schmidt,andVassilou Y. DAIDA, Conceptual Model-ing and Knowledge Based Suppor of Information Systems Development Process. Technique et Science Informatiques, 1990,122133.

[4] Jean-François CARPENTIER, La gouvernance du Système d'Information dans les PME : Pratiques et évolutions, Editions ENI, Mars 2017.

[5] Bruno Ménard, CobiT : Pour une meilleure gouvernance des systèmes d'information, Eyrolles, janvier 2009.

[6] Frédéric Georgel, IT Gouvernance: Maîtrise d'un système d'information, Dunod, Mai 2005.

[7] Richard Basque, CMMI 1.3-Guide complet de CMMI-DEV et traduction de toutes les pratiques CMMI-ACQ et CMMI-SVC, Dunod, Mai 2011.

[8] Gmati, I., Nurcan, S., Gmati, I., \&Nurcan, S. Un cadre de référence pour analyser les exigences d'alignement métier / système d'information, 2012.

[9] Abbadi, S. S.-M.-L..Proposition de méthode d'implémentation d'ITIL. 2eme édition du congre International de génie Industriel et Management des systèmes, 2015, Mai 21, pp. 5,6.

[10] Rolland, C.. A Comprehensive View of Process Engineering, 2012, 124.

[11] Commerce, O. o. ITIL 2011 Amélioration continue des services. stationery office, 2011.

[12] Commerce, O. o. ITIL 2011 Conception des services, stationery office. stationery office, 2011.

[13] Commerce, O. o. ITIL 2011 Exploitation des services. stationery office, 2011.

[14] Commerce, O. o. ITIL 2011 Stratégie des services. stationery office, 2011.

[15] Commerce, O. o.ITIL 2011 Transition des services. stationery office, 2011.

[16] Martine Otter, J. S. Guide des certifications SI. Dunod, 2009.

[17] Z. Ibn Batouta, Multi-criteria analysis and advanced comparative study between automatic generation approaches in software engineering, 2015. Vol.81. No.3.

[18] Ken Schwaber, Jeff Sutherland, "The Definitive Guide to Scrum: The Roles of the Game", 2017 Edition, available at www.scrum.org.

[19] AXELOS, "Managing Successful Projects with PRINCE2", 2017 Edition.

[20] H. Askari, H.Mohammad khan, L. Mydin, "Reformation and Development in the Muslim World: Islamicity Indices as Benchmark", Springer 2017 Edition.

[21] R. Tricker, "ISO 9001:2015 for Small Businesses", 2016 Edition.

[22] CIGREF, "Les référentiels de la DSI", 2009 Cigref Edition. 